\section{Nuclear Reactors for British Universities}

Is a written answer on April 17 the Parliamentary Secretary for Science, Mr. D. Freeth, said that one low-power nuclear reactor was being built for the use of the Royal College of Science and Technology, Glasgow, all the Scottish universities and Queen's Univorsity, Belfast. The Government had agreed in principle to make grants for the provision of two further reactors, one in Lancashire and one in the London area. A request for a second reactor at the University of London had boen deferred and several universities had been told that there was no early prospect of grants being made. A grant of up to $£ 255,000$ had been made for the reactor for the Scottish universities and he hoped that the two further grants, totalling more than $£ 500,000$, would be announced later this year.

\section{Air Pollution by Diesel Fumes}

The Diesel Fumes Bill, which received a second reading in the House of Commons on April 6, was withdrawn aftor the Parliamentary Socretary to the Ministry of Transport, Mr. John Hay, assured the House that the Bill added little to the wide powers which the Ministry already possessed to deal with the problem under Section 64 of the Road Traffic Act. Already the Minister had power to prescribe densities of sinoke and visible vapour and to prescribe that additives must be used in all Diesel engines. How ever, he suggested that Mr. R. Speir should proposo an amendment to the Road Traffic Bill with the effect of Clause 3. This Clause allows Diesel-engined vehicles not already subject to special provisions about inspection to be tested at the roadside when reliable measurement is possible. Earlier, Mr. Hay referred to the very wide programme of research into air pollution which had been and was still being carried out by the Medical Research Council. Research work has not revealed any specific threat from Diesel fumes alone in the concentration in which they are found in city streets. Petrol engine exhausts are likely to be the main hazards, and tho results of research in the United States in such fields are being watehed as the problem there is far more acute. Mr. Hay repeated that extensive tests by the Department of Scientific and Industrial Research have established that a well-maintained and properly driven Diosel-ongine vehicle does not normally emit any more than a slight puff of smoke. Neither fucl additives nor filter devices are as fruitful a field for reducing dark smoke as proper maintenance and adjustment of the engine. Mr. Hay said that during 1960-61 there were 1,875 prosecutions, and it was difficult to ensure that enforcernent of the existing powers could bo much improved although various possibilities were being examined. Furthermore, the law has recently been strengthened by a now regulation which from January 1, 1962, forbids the misuse by the driver of a Diesel-engined vehicle of the excess-fuel device, which in certain circumstances can provide extra power at the cost of black smoke. The regulation also requires control for the device on now vehicles to be such that it cannot be operated when the vehicle is moving and older vehicles have to be modified in this respect by July 1.

\section{The British Aerosol Manufacturers' Association}

THE first annual report of the British Aerosol Manufacturors' Association, covering the year ended December 31, 1961, records the provisional approval of a draft specification for metal containers for aerosol dispensers (Pp. 12. London: British Aerosol Manufacturers' Association, 1962). These specifications are to be considered by a technical committee of the British Standard Institution bofore circulation to industry for comment. The Executive Committee also rocommended during the year that all aerosol containcrs filled by members should bear precantionary wordings. Detailed statistics of the aerosols filled by member firms during 1960 and 1961 have been collected and are listed. It is still open for discussion whether membership of the Association should be extended to include manufacturers of equipment and machinery.

\section{Pollution by Agricultural Wastes}

Aттнолян pollution of rivers is usually attributed to sewage or to discharges from factories, agricultural wastes cause trouble in many areas. This is emphasized in the seventh annual report of the Tweed River Purification Board, where it is pointed out that farm efflucnts, such as drainage from silage pits or pig. geries, may be very strong and may overload a sewage works if they are discharged to a sewor (Pp. 46. Newtown St. Boswells: Tweed River Purification Board, 1961). 'The presence of traces of toxic insecticides or herbicides can also interfere with biological processes of sewage treatment. In an appendix to the report, information is given on the volume and composition of waste waters from a relatively new and rapidly expanding agricultural industry - poultry packing - obtained as the result of an investigation at a packing station in south-east Scotland. To give some idoa of their polluting character, they are compared with those from a slaughter-house; on the basis of the demand for biochemical oxygen, the waste liquor from processing $12 \cdot 5$ turkeys or $32 \cdot 3$ chickens is equivalent to that from slaughtering one pig.

\section{The Case Against Decimalization}

Prof. A. C. AItKen, in a pamphlet entitled The Case Against Decimalisation, presents very skilfully the case against docimalization in general, starting with a lucid and cogent historical review (Pp. 22. Edinburgh and London: Oliver and Boyd, Ltd., 1962. 2s. 6d.). He is less persuasive, however, in arguing for the duodecimal system, adoption of which in coinage, with a pound of twelve shillings, he suggests. He claims that this is a much more efficient system than the decimal system and that its adoption offers substantial advantages on practical as well as on arithmetical grounds.

\section{Committee on the Problem of Noise}

The Committee set up in April 1960 by the Minister for Science under the chairmanship of Sir Alan Wilson has now fixed May 15 as its closing date for receiving written evidence concerning the nature, sources and effects of the problem of noise, and further measures which can be taken to mitigate it. Organizations and persons who intend to submit written evidence should send it to the secretary of the Committee, Mr. R. S. Matthews, at the Ministry of Health, Savile Row, London, W.l.

\section{The Ciba Foundation}

Tine report of the Ciba Foundation for 1961 records the holding of seven general international symposia on very varied subjects as well as a colloquium on the detection and assay of hormones by immunochemical means, and the fourteenth meeting in the series of colloquia on endocrinology. Four study groups were 